Bentley, Anna. "The Fortunes of Hungarian Children's Literature at Home and in the English-Speaking World." Hungarian Cultural Studies. e-Journal of the American Hungarian Educators Association, Volume 14 (2021):

\title{
The Fortunes of Hungarian Children's Literature at Home and in the English-Speaking World
}

\section{Anna Bentley}

\begin{abstract}
This paper asks why so few works of Hungarian children's literature have made it to publication in English-speaking countries. It finds that few translated children's books make it onto the English-language market and those translations that are successful mainly appear in major European languages. Representation at the Bologna Children's Book Fair has been dogged by a lack of financial resources and polish while Hungarian State funding has lacked continuity. Nearly all the English translations of Hungarian children's books available today have been published in Hungary, although a book will occasionally find its way to foreign publishers by informal means. This paper also follows the development of Hungarian children's literature from the late nineteenth century to the present day, noting changes in terms of character, subject matter and attitudes to diversity and use of the fairytale tradition. It outlines one recent controversy surrounding the publication of Meseország mindenkié ['Storyland for Everybody'], a book which aims, in contrast to the current regime's ideology, to represent the marginalized in Hungarian society. It also details recent clashes sparked by the new Hungarian National School Curriculum and one writer's feminist critique of a classic text.
\end{abstract}

Keywords: Hungarian children's literature, fairy tales, diversity, Meseország mindenkié, English translation, publishers, book-shredding, National Curriculum, Móra Könyvkiadó, Pozsonyi Pagony, Bologna Children's Book Fair, Petöfi Literary Fund

Biography: Anna Bentley is a freelance British literary translator based in Budapest since 2000. Her translation of Ervin Lázár's children's classic, Arnica the Duck Princess was published by Pushkin Children's Press in 2019. In the same year, her translation of Anna Menyhért's study of five forgotten Hungarian women writers, Women's Literary Tradition and Twentieth-Century Hungarian Writers, was published by Brill. Her translations of poetry and prose have appeared in Asymptote's Translation Tuesday blog, in Trafika Europe's online journal, in Consequence Magazine and on Hungarian Literature Online. annaatbudapest@gmail.com

In recent years, it has been pleasing to see a handful of Hungarian authors and their translators winning recognition in the English-speaking literary world. Nearly every book that has succeeded in attracting the attention of English-language publishers was, however, written for adult readers. What, then, does Hungarian children's literature have to offer, and why is it failing to reach readers in the English-speaking world? I will endeavour to answer these questions by looking at how Hungarian children's fiction has developed over the last century or so (touching on poetry only briefly) and what characterizes it today. I will also discuss what has 
Bentley, Anna. "The Fortunes of Hungarian Children's Literature at Home and in the English-Speaking World." Hungarian Cultural Studies. e-Journal of the American Hungarian Educators Association, Volume 14 (2021): http://ahea.pitt.edu DOI: 10.5195/ahea.2021.433

been translated into English, as well as what funding is available for such translation and promotion under the aegis of the new Petöfi Literary Fund. Finally, I will discuss how the issue of what children read has become a touchstone for the ideological conflict between right-wing "conservative" and liberal politics within Hungary.

\section{Hungarian Children's Literature: the Past}

In her book on the children's author, Éva Janikovszky, the Hungarian literary historian Gabriella Komáromi divides Hungarian children's literature into two great eras: the first extends from the end of the nineteenth century to the 1920s, and includes writers such as Ferenc Molnár (1878-1952), Kálmán Mikszáth (1847-1910), Géza Gárdonyi (1863-1922), Zsigmond Móricz (1879-1942), Frigyes Karinthy (1887-1938) and Ferenc Móra (1879-1934); the second, so-called "golden age" of Hungarian children's literature stretches from the 1950s to the late 1980s and includes Sándor Weöres (1913-1989), Zoltán Zelk (1906-1981), István Kormos (1923-1977), Ágnes Nemes Nagy (1922-1991), Ervin Lázár (1936-2006), Éva Janikovszky (1926-2003), Iván Mándy (1918-1995), Magda Szabó (1917-2007), István Fekete (1900-1970), István Csukás (1936-2020) and Pál Békés (1956-2010) (Komáromi 2014: 250).

The first wave of writing for children came after an increase in awareness of the need for good-quality, original writing for children in the Hungarian language, and concern about the diet of poor translations from German-language writers available at the time. In 1888, a young parliamentary representative from Transylvania called Elek Benedek (1859-1929), the man who would come to be known as "the great storyteller" for his seminal folk tale collection, Magyar mese- és mondavilág ['The World of Hungarian Folktales and Proverbs'] published between 1894 and 1896, appealed to the National Assembly for more support for Hungarian children's literature. The following year, Benedek and Lajos Pósa (1850-1914) started Az Én Újságom ['My Newspaper'], a children's magazine aimed at the six- to ten-year-old age group, to which they persuaded well-respected writers for adults to contribute (Komáromi 1990:15).

Works of fiction produced over the subsequent decade or two are still on the school syllabus for older children in Hungary. Examples include Molnár's A Pál utcai fiúk ['The Paul Street Boys'] (1906) and Gárdonyi's Egri csillagok ['Eclipse of the Crescent Moon'] (1899), still required reading in grades seven and eight, according to the new Hungarian National Curriculum (Oktatási Hivatal 2020b); Mikszáth's Szent Péter esernyője ['St. Peter's Umbrella'] (1895) and Móricz's Légy jó mindhalálig ['Be Faithful Unto Death'] (1920) are still "core material," and Karinthy's Tanár úr kérem ['Please, Sir!'] (1916) is "recommended material" for the same grades; for younger pupils, poems and short stories by Móra are core or recommended material (Oktatási Hivatal 2020a). Many other works by these writers still feature in the curriculum. The child's world of school, home, and the territory in between, is the setting for both Molnár's and Karinthy's works. The Paul Street Boys tells the story of an urban group of boys' valiant defence of an empty lot they have claimed for themselves and is an enduring classic about patriotism, life and death. Karinthy, by contrast, provides a humorous portrayal of the scrapes a city schoolboy gets into. Gárdonyi's book is a historical romance about the Siege of Eger in 1552 by the Turks, while Mikszáth's love-cum-detective story, while not obviously meant for children, has, by virtue of its magical elements and gentle portrayal of society in the far-flung northern regions of the country (now part of Slovakia), come to be regarded as appropriate for children. Móricz's 
Bentley, Anna. "The Fortunes of Hungarian Children's Literature at Home and in the English-Speaking World." Hungarian Cultural Studies. e-Journal of the American Hungarian Educators Association, Volume 14 (2021): http://ahea.pitt.edu DOI: 10.5195/ahea.2021.433

intense, tragic story of a boy accused of theft at a boarding school in the eastern city of Debrecen, is, however, perhaps more appropriate for adults despite the child protagonist.

The second period is inextricably associated with the publisher Móra, known until 1957 as Ifjúsági Kiadó ['Young People's Publishing House']. As the sole publisher of children's literature, it became a haven for writers such as Ágnes Nemes Nagy and Magda Szabó when they were not permitted to publish elsewhere due to their background or political views but allowed to make a living through literary translation and writing for children. While Nemes Nagy and Sándor Weöres stand out for their contribution to children's poetry, with Weöres's musical poems in particular still much loved by children as well as adults today, when it comes to prose, the literary historian and children's literature researcher Andrea Lovász picks out the "triad" of Ervin Lázár, Éva Janikovszky and István Csukás who, she says, "left their mark of quality on the seventies and eighties and the two decades that followed, their three differing voices offering enduring and useful reference points in children's literature" (Lovász 2008).

Lázár and Csukás are both described as writing in the genre of the mümese ['literary fairy tales']. Lázár in particular played with elements from the world of Hungarian fairy tales when he introduced characters such as the good Seven-Headed Fairy into his stories; his readers knew that traditionally it was wicked dragons who were seven-headed. (These dragons, incidentally, are more like rich, jealous husbands in their behavior and fly on the backs of magic steeds rather than being the fire-breathing, winged reptiles we know from English tradition and Tolkien.) While some of his stories, such as Szegény Dzsoni és Árnika ['Arnica the Duck Princess'], are peopled with witches, kings and princesses, they also include references to soccer and modern technology, and the demons that must be defeated are often internal, as in the case of Victor Coppermine, who must learn not to be continually taking offense. Csukás is best known for Süsü the Dragon, a character he inherited but made his own. Contrary to his family's expectations, Süsü is gentle and meek, loyal and loving. Both writers also created their own zany worlds: Lázár's A négyszögletü kerek erdö ['The Four-Square Round Forest'] abounds with curious figures like Dömdödöm, who never says anything other than the nonsense word, dömdödöm, a blue horse, a green fairy, a retired circus lion, a very bright rabbit and a walking fir tree. Csukás's world includes Pom Pom, a shapeless hairy creature that likes to ride on the top of the little girl Picur's head and Gombóc Artúr ['Arthur Dumpling'], a plump bird obsessed with eating chocolate.
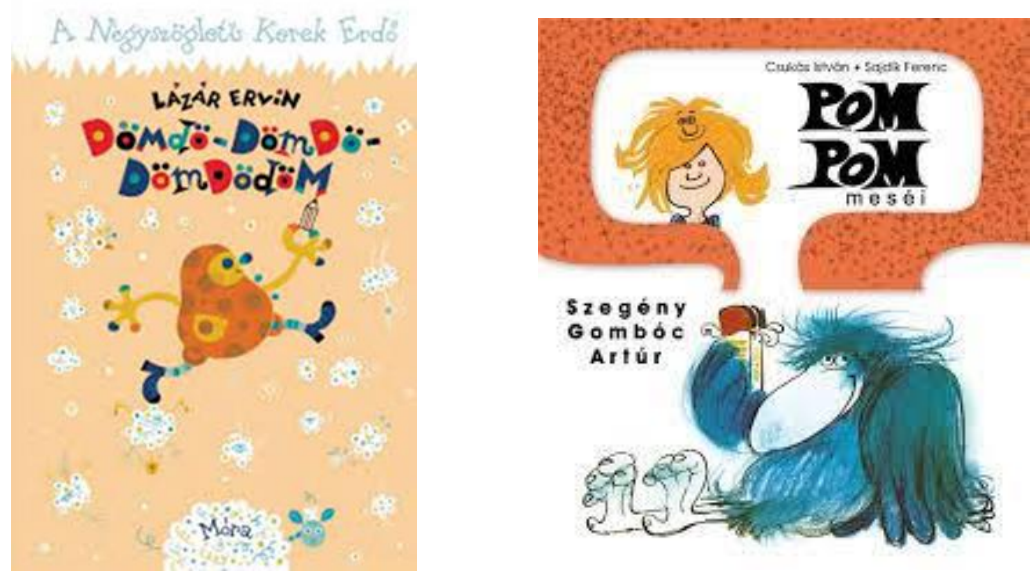
Bentley, Anna. "The Fortunes of Hungarian Children's Literature at Home and in the English-Speaking World." Hungarian Cultural Studies. e-Journal of the American Hungarian Educators Association, Volume 14 (2021): http://ahea.pitt.edu DOI: 10.5195/ahea.2021.433

Janikovszky's world (illustrated in spare, stick-figure style by László Réber) is, by contrast, the everyday world of kindergarten, school and the traditional family home, and offers the reader not stories, but rather "meditative" monologues relayed in a child's voice (Komáromi 2014:96) that present the conflict between the world as seen by children (at face value) and by adults, who, aware of its complexities, often resort to cliché and long-established patterns in their responses to children. It was in this period, says Lovász, "that what are regarded today as the basic principles of classic Hungarian children's literature were established: in terms of content this meant fiction, plenty of fairy-tale-like action and children as protagonists within a framework of the traditional family model; and, in terms of language, an increasing appreciation of humor, irony and children's own use of language" (Lovász 2008).

The publication in 1983 of Pál Békés's book A kétbalkezes varázsló ['The Ham-Fisted Wizard'], saw the introduction of "a new world of story-telling and a new children's world, one that was open to social and ethical problems" (Lovász 2008). The bungling wizard of the title is posted as the "district wizard" in a modern communist housing estate of uniform ten-story tower blocks. He discovers fairy-tale figures, who are living unhappily in the apartments having been moved from their old dwellings to make way for a chemical factory and given new jobs in the modern economy. The monsters this wizard fights are the big metal bins in the basement and the creature who supposedly inhabits the heating system.

The 1960s and 70s also saw the arrival of Veronika Marék's classic Boribon series for younger children. Still immensely popular, these are produced in a smaller format $(19.5 \mathrm{~cm}$ by $16.5 \mathrm{~cm}$ ) and tell short, simple stories of the everyday adventures of a little girl called Annipanni and her teddy bear, Boribon. Their relationship is partly that of friends and partly that of parent and child. The illustrations, by the author herself, are bold and simple with bright, solid blocks of color. These were followed in the 1980s by her Kippkopp series about Kippkopp the "conker child." (Hungarian children make little figures in the autumn out of conkers ['horse chesnuts' in American English] and matchsticks). Kippkopp's adventures are those of a tiny creature among flowers and creatures of similar size. He acquires a family during the series and the whole cast have appeared on puppet theater stages - appropriately enough, given Marék's original training as a puppeteer.
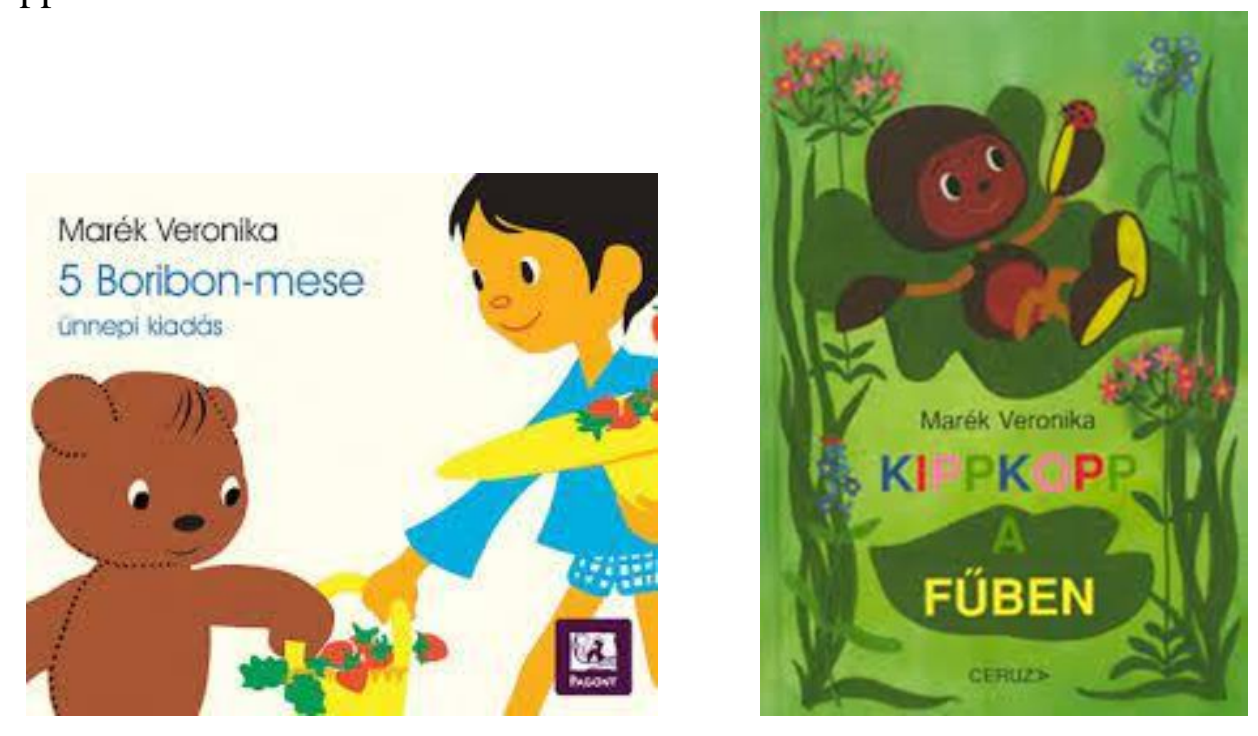
Bentley, Anna. "The Fortunes of Hungarian Children's Literature at Home and in the English-Speaking World." Hungarian Cultural Studies. e-Journal of the American Hungarian Educators Association, Volume 14 (2021): http://ahea.pitt.edu DOI: 10.5195/ahea.2021.433

With the fall of communism, Móra's monopoly on children's publishing in Hungary came to an end and, with the loss of state funding and the collapse of its distribution network, it could not continue to publish the number of titles it had in the past and was obliged to let many of its writers go. In 1992, it was privatized. The nineties saw the advent of hundreds of small, new publishers, many of whom would fall by the wayside, and an influx of foreign books into the children's book market. In 2021, Móra is still present on the children's book publishing scene, but faces stiff competition, especially when it comes to contemporary Hungarian children's books. This is illustrated by the 2020 shortlist for the Hungarian Children's Book of the Year, in which no fewer than seven books from the award-winning publisher Pagony appear, while Móra had only one title on the list. (Könyves Magazin 2020a)

\section{The Present Situation in Children's Book Publishing}

Pagony has acquired most of Veronika Marék's Annipanni and Boribon books and, using the same format, publishes the very popular Bogyó és Babóca ['Berry and Dolly'] series by author-illustrator, Erika Bartos. For slightly older readers, they also publish the successful Kufli series, written and illustrated by András Dániel, the first book of which came out in 2013. The kuflis, which arrive from who knows where in the first book and dig themselves burrows in the side of a small hill, are 'neither kukacok ['maggots'] nor kiflik ['crescent-shaped bread rolls common in Hungary'], but, as their portmanteau name (ku-fli) suggests, look like a cross between the two. Not only are Dániel's characters difficult to define, his stories about them also wriggle out of our grasp when we try to pin them down. As Boldizsár M. Nagy says,

in his formally innovative books, András Dániel repeatedly overrides the well-trodden picture-book schemata... and is able for the umpteenth time to surprise us. The creatures that live on the 'Abandoned Meadow' (mostly used for lolling about on)... confront issues of philosophy, aesthetics and even theoretical physics. Their stories are not adventure-centered, being rather a sequence of scenes of a meditative nature, in which free rein is given to play and creativity (Nagy B. 2020).

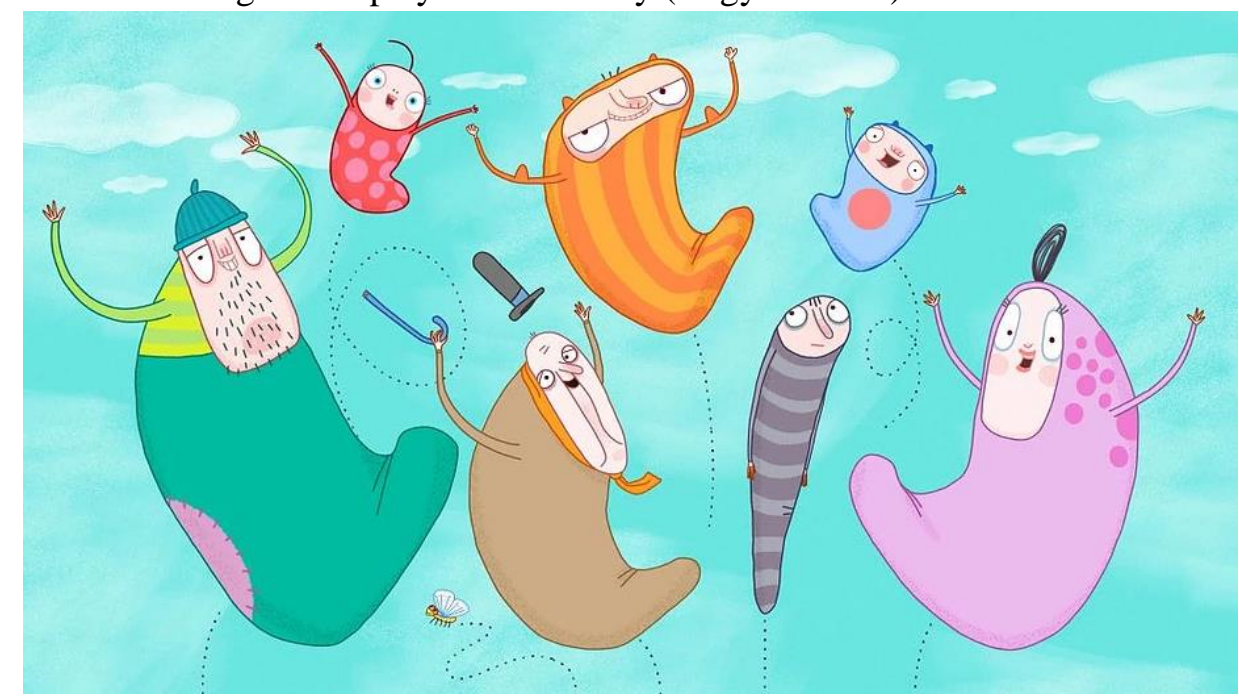

Illustration from the animated series The Kuflis (KEDD Studio) 
Bentley, Anna. "The Fortunes of Hungarian Children's Literature at Home and in the English-Speaking World." Hungarian Cultural Studies. e-Journal of the American Hungarian Educators Association, Volume 14 (2021):

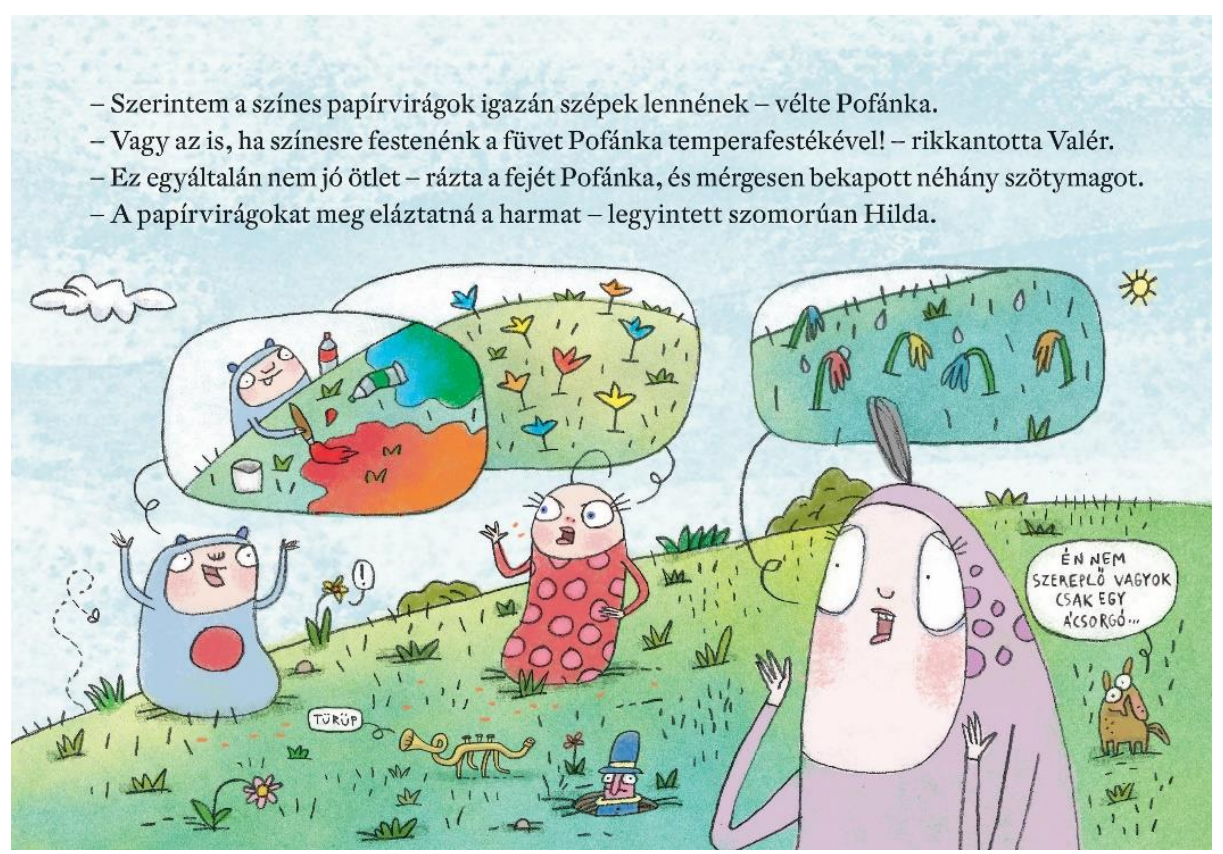

From Tengerre kuflik! [To Sea, Kuflis!]

One feature of these books is the rather postmodern commentary offered in the speech bubbles of strange little extraneous creatures, such as when one unidentifiable creepy-crawly in the margins of Tengerre kuflik! ['To Sea, Kuflis!'] asks another, "What do you think, is there a moral to this story?" [Szerinted van ennek a történetnek tanulsága?]. In Zsebseprü a szötymag ellen ['Pocket Brooms versus Sunflower Seeds'], the second story in the book, a ratlike creature remarks, "I'm not a character, I'm just hanging around" [Én nem szereplö vagyok, csak egy ácsorgó].

For the middle-school, eight-to-twelve-year-old age-group, Pagony has also been responsible for introducing Judit Berg's Rumini series, which now extends to eight volumes, about the adventures of a sea-going mouse which has spawned a stage show and other publications. Erzsi Kertész's Panthera adventure series is also published by Pagony, along with her witty and wise Nem Mese ['The NO Story'], in which a boy is taught by a shape-shifting and color-changing creature called the NO about the many different ways in which he can say "no," starting with politely declining a well-meaning neighbor's offer of some cakes. Kertész's Labirintó ['Labyrinth Lake'], published by Cerkabella in 2018, also plays to some extent with fairy-tale tropes. Rather than making the hero the youngest son, Kertész's protagonist is the oldest one, but triumphs nevertheless. The author exploits the tensions arising from its odd characters (some reminiscent of Lázár's Four-Square Round Forest-dwellers) being confined at close-quarters on a gondola as they punt through the lake's archipelago. Two more daring offerings from Pagony for this age group are the 2018 Egy fiú a csapatból ['A Boy from the Team'] by Dóra Igaz, the first Hungarian children's book to tackle the Holocaust, and Zsófia Bán's Vagánybagoly és a Harmadik Á ['Rough 'n Tough Owl and Third Grade A'], in which the owl of the title helps a group of schoolchildren to be more accepting of otherness: one child has 
Bentley, Anna. "The Fortunes of Hungarian Children's Literature at Home and in the English-Speaking World." Hungarian Cultural Studies. e-Journal of the American Hungarian Educators Association, Volume 14 (2021): http://ahea.pitt.edu DOI: 10.5195/ahea.2021.433

two mothers, another is foreign (possibly a "migrant"); the group also overcomes its fear of a homeless man.

In 2013, Pagony launched an imprint for young adults called Tilos az Á. Móra’s X series of the early 2010s has more recently given way to its LOL series of teenage romances. This area of children's publishing was dominated for a while after the fall of communism by foreign books in translation, but is now seeing Hungarian writers taking up the challenge, from Eszter $T$. Molnár's Stand-Up series (launched in 2016), which deals with life in a dysfunctional family, and Ágnes Mészöly's Szabadlábon ['Walking Free'] (2016), about a wheelchair-using teenage boy who runs away from home, to Balázs Zágoni's science-fiction novel A gömb ['The Sphere'], winner of the Book of the Year Young Adult category in 2019. Móra has also brought out a series of thematic short-story collections for young adults by contemporary writers, starting with Jelen! ['Present!'], which won the 2015 Children's Book of the Year Young Adult category.

Other recent developments in Hungarian children's literature include a more inclusive approach to the folk tradition, with collections of tales from minority communities, like Móra's $A$ büvös puska ['The Magic Rifle'] (2015), Gypsy tales collected from the Croatian-speaking minority in the south of Hungary by György Frankovics, and Kolibri's A rabbi és az oroszlán ['The Rabbi and the Lion'] (2018), Jewish folktales and sayings collected from a mixture of English-language, Yiddish and Hungarian sources by Mária Bajzáth. In 2019 Móra published storyteller Csenge Virág Zalkai's Ribizli a világ végén ['Redcurrant at the End of the World'], the first Hungarian attempt at producing a feminist folktale collection. In Boldizsár M. Nagy's words, 'In the world of the familiar, sexist Hungarian folktale, it is as if Sleeping Beauty were awakening from a coma she was forced into, making it possible at last to see how colorful and varied our folk culture really is [A jól ismert, szexista magyar népmesei közegben mintha felébredne a kómába kényszerítet Csipkerózsika, és végre látjuk, népi kultúránk milyen színes valójában] (Nagy, Boldizsár M. 2019). Interestingly, although these three volumes have been produced by two different publishers, they are visually of a piece thanks to the strong colors and densely packed detail of their common illustrator, László Herbszt's instantly recognizable style.
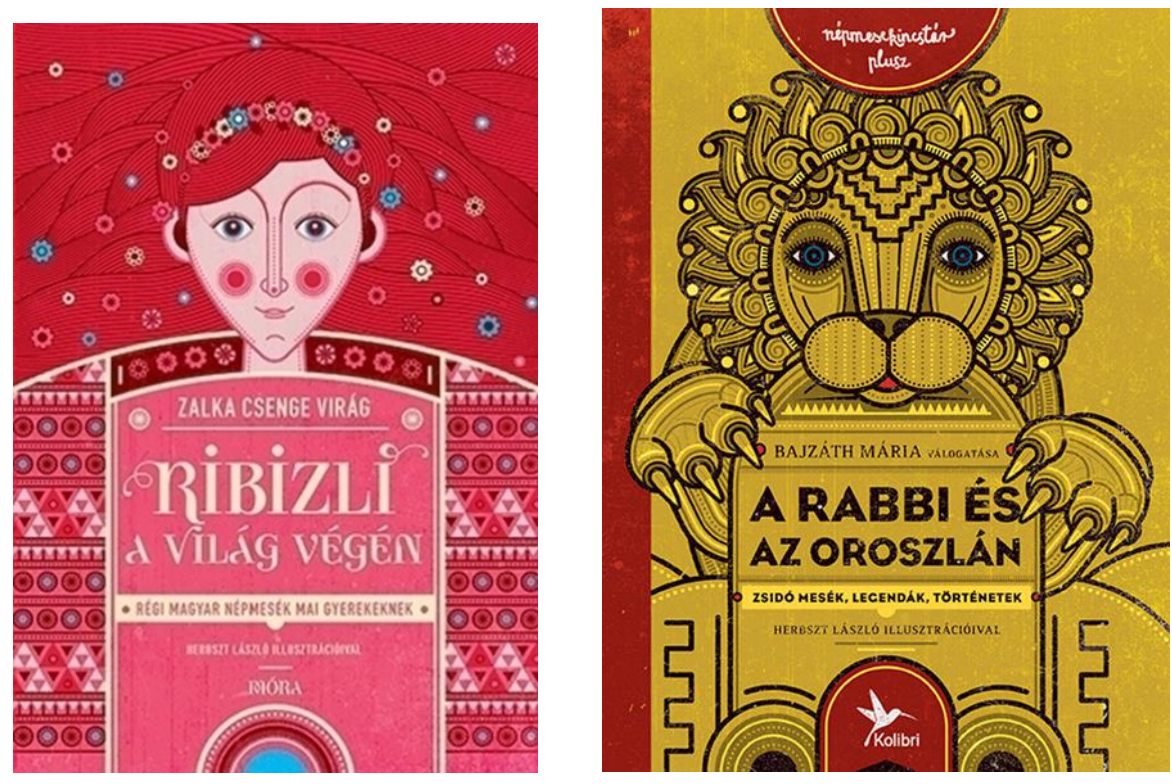
Bentley, Anna. "The Fortunes of Hungarian Children's Literature at Home and in the English-Speaking World." Hungarian Cultural Studies. e-Journal of the American Hungarian Educators Association, Volume 14 (2021): http://ahea.pitt.edu DOI: 10.5195/ahea.2021.433

Independently of Frankovics's volume, it is interesting to see a new use of folk-tale forms in Krisztina Tóth's book A lány aki nem beszélt ['The Girl Who Didn’t Speak'] (Móra 2015). The story of a girl born to and abandoned by a Gypsy couple living in the woods, who is then adopted by a family in the village and eventually reunited with her birth parents and finds her human voice in the process, not only argues for a meeting of minds and exchange of cultural knowledge between the settled community and the nomadic one, the mainstream population and the minority Roma, but also uses patterns and themes from Gypsy folktales. It is an "origin story" of sorts, of the kind often found in the Gypsy folk tradition and, as Gabriella Ágnes Nagy points out, "shapes ... at the level of the plot a fairy-tale narrative which rewrites the Hungarianlanguage folk-tale tradition of the Roma, and places the Roma way of life in a cultural and social context" [A cselekmény szintjén tehát olyan mesei narratívát alkot meg, amely újraírja a magyar nyelvű cigány népmesei hagyományt, valamint a cigányok létmódját kulturális-társadalmi kontextusba helyezi] (Nagy G. Á. 2017: 55). The rewriting of specific fairy tales from different points of view, or in order to challenge the presentation of gender roles is, of course not new in the English-language children's literature world. (See Robert Munsch's The Paper Bag Princess 1980 and Roald Dahl's 1982 Revolting Rhymes, and for the braver reader, Angela Carter's Book of Fairy Tales 1992). I will return to this topic when I discuss the collection Fairytales for Everyone.

An exciting range of Hungarian children's literature exists, then, ranging from the early classic works of fiction, through the 'golden age' of stories and poetry in the fifties to the seventies, to the varied palette of present-day publication for children, with its wider range of genres, its more diverse subject matter and its celebration of the possibilities of language as a source of fun and experiment.

\section{Translation of Hungarian Children's Literature}

There is actually more of this literature available in English (at least in Hungary) than might be assumed from the opening paragraph of this essay, as a virtual visit to the children's section of the almost three-decade-old English-language Budapest bookshop, Bestsellers, will show. As of April 2021, the shop's website is offering the following works in English translation from the "first period:" The Princess of the Wind, a collection of fairy tales from Elek Benedek, translated by Elizabeth Demeter (Corvina 2014), Ferenc Molnár's The Paul Street Boys in an "updated" version of L. Rittenberg's 1927 translation (Corvina 2018), Géza Gárdonyi's The Eclipse of the Crescent Moon, translated by G. F. Cushing (Corvina 1991) and Zsigmond Móricz's Be Faithful Unto Death, translated by Stephen Vizinczey (CEU Press 2015.)

From the second "golden" period we find no fewer than seventeen titles by Éva Janikovszky (Móra), three by Veronika Marék (Móra), two by Ervin Lázár (Pushkin Children's Press and Móra) and one by István Fekete (Móra). More recent children's writing is represented by two Berry and Dolly books by Erika Bartos (Pagony), one by Ancsa Hohol also for young children (Móra), and one volume from Judit Berg's Rumini series (Pagony.) It can be seen that, with the exception of Ervin Lázár's Arnica the Duck Princes, all of these volumes have been issued by Hungarian publishers. The predominance of Éva Janikovszky is perhaps explained by the fact that since it was privatized, Móra has been owned in part by Janikovszky's son, János Janikovszky (the model for the little boy who grows up through the books), and her books are regularly reprinted by the publisher.

Móra's current offerings in English can be seen from their 2020 flyer (Móra 2020). Móra has published twenty-two titles in English to date and in recent years also six bilingual books. 
Bentley, Anna. "The Fortunes of Hungarian Children's Literature at Home and in the English-Speaking World." Hungarian Cultural Studies. e-Journal of the American Hungarian Educators Association, Volume 14 (2021): http://ahea.pitt.edu DOI: 10.5195/ahea.2021.433

According to Katalin Vas, Head of Publishing and Operations at the publishing house, "it has long been important to Móra that the 'golden oldies' of Hungarian children's literature be available in foreign languages...they also come in very useful when we would like to sell the foreign rights of certain works." Their flyer, she says, "was produced for schools, libraries and institutions (in Hungary) where the English language is studied and used, or where English is the language of instruction." These books are bought by "foreigners living in Hungary, Hungarians or foreigners living abroad ...it's a very varied picture." In response to my question about whether British or American publishers have enquired after any of their books, she replied, "For the time being, word of Central European children's literature gets through to them only with the greatest difficulty." (Personal communication, 2021).

The fact remains that very few translated books are published in English, and of those, very few are children's books. In 2018, Kirsten Malmkjær wrote that,

Out of the $3 \%$ of all books published in the UK each year that are translated, only $1 \%$ are children's books (Hallford and Zaghini 2005: 5). A later study (Donahaye 2012: 4) suggests that the percentage of books published in the UK that are translated is in fact "consistently greater than 4\%", but unfortunately, an even later Media Release, published 13th April 2015 by Literature Across Frontiers (http://www.lit-across-frontiers.org/new-translation-statisticsfrom-laf/) defends the 3\% view. Anyway, the number of translated books for children published in the UK is small' (Malmkjær 2018).

In a review of translated children's books published in the UK between 2005 and 2014, Deborah Hallford of Outside In World noted that,

470 titles were translated.... Of this, 443 were titles translated from European countries. The top five languages were:

- French 193

- German 91

- Dutch 40

- Swedish 37

- Danish 18 (Hallford 2016)

From these figures, it is clear that a small group of Western European and Scandinavian European languages dominate the translated children's book offerings in the UK. In an article about the issue in the United States in 2019, Elizabeth Bird wrote that,

The Cooperative Children's Book Center (CCBC) at the University of Wisconsin is the source of the most authoritative data on translated children's literature. In 2018, it counted 169 children's books in translation, about $4.56 \%$ of the total it received. That number has increased an average of $9 \%$ each year since 2002, when the CCBC identified only 75 translations, representing $2.38 \%$ of the total books that year (Bird 2019). 
Bentley, Anna. "The Fortunes of Hungarian Children's Literature at Home and in the English-Speaking World." Hungarian Cultural Studies. e-Journal of the American Hungarian Educators Association, Volume 14 (2021): http://ahea.pitt.edu DOI: 10.5195/ahea.2021.433

In the same article, she also observed that, "The CCBC's data reveals that $72 \%$ of total children's book translations in 2018 came from just four languages-French, German, Italian and Spanish."

The chances of a Hungarian children's book being picked up by a British or American publisher do appear to be very slim indeed. The reasons for this may include publishers being more likely to have an editor who reads one of these major languages; there simply being a greater quantity of French and German children's literature and its being better promoted, and a self-perpetuating unfamiliarity with a culture that for many decades was out of reach behind the Iron Curtain.

It is perhaps useful at this this juncture to look at how two Hungarian children's books have managed to make it to publication abroad, one while the Iron Curtain was still firmly in place, another much more recently: Éva Janikovszky's Ha én felnött lennék ['If I Were a GrownUp'] in West Germany in 1972, and my own translation of Ervin Lázár's Arnica the Duck Princess in Britain in 2019. In both cases their publication was not due to any effort on the Hungarian publisher's part, but instead a chance encounter by an individual outside the publishing world who then succeeded in exciting the foreign publishers' interest.

Around 1970, a young West German teacher was in Hungary learning to ride. She asked her riding teacher to help her with her Hungarian, and he decided that Janikovszky's book would be a useful resource. Together they put together a rough translation of it which she took back to Germany with her and showed to some friends of hers. These friends were just setting up a tiny publishing company in a garage in Mülheim that was to become Anrich Press. In 1972, they put the book in, under the German title Große Dürfen Alles ['Grown-ups Are Allowed to Do Anything'] (most likely translated by Irene Kolbe) for the Deutscher Jugendbuchpreis, and it was selected as the winner in the picture book category. Since then, Janikovszky's books have been translated into thirty-five other languages (Komáromi 2014: 57-60).

In 2016, my eleven-year-old daughter was assigned Lázár's book by her Hungarian teacher as summer reading. I read it, too, and was so charmed by it that I decided to translate it as a private exercise in the craft. I pitched a sample to Pushkin Children's Press. Some six months later, they replied, asking for more chapters. No more word came, however, until a few months later, when I was attending the British Centre for Literary Translation Summer School in Norwich, where my workshop leader, the British literary translator Daniel Hahn, introduced me to Pushkin's assistant editor who had come up from London to take part in a publishers' panel discussion at the Summer School. A British children's writer I knew also put in a word for the book. By November of 2017, I had received a contract. Ervin's book, therefore, came to the attention of a British publisher partly through a non-Hungarian accidentally coming upon the book, being impressed by it, and making the case for its publication. It probably helped that Lázár was an established name in Hungary, that his books were available in other languages, and that he had received the Children's Book of the Year award from the Hungarian IBBY three times.

A more obvious route for children's books to come to the attention of UK and American publishers is, of course, the Bologna Children's Book Fair. While the Hungarian Illustrators' Association had been participating at the Fair since 1995, it was only from 2002 that Hungary had its own stand, run by the Illustrators' Association, with state support from the National 
Bentley, Anna. "The Fortunes of Hungarian Children's Literature at Home and in the English-Speaking World." Hungarian Cultural Studies. e-Journal of the American Hungarian Educators Association, Volume 14 (2021): http://ahea.pitt.edu DOI: 10.5195/ahea.2021.433

Cultural Heritage Ministry (Nemzeti Eröforrás Minisztérium 2006). Although Hungary was the guest of honor at the fair in 2006, between 2007 and 2018 it was sometimes represented on the smallest of stands (Pompor 2010) and was absent altogether in 2016. Art historian Emese Révész's article on the 2019 fair, when the newly reformed Hungarian section of IBBY (HUBBY) was not invited by the state body running it, gives a less than flattering picture of the impression the Hungarian stand made on that occasion and suggests that this was the rule rather than the exception: "The failure of the Hungarian stand to impress is the result of the accumulated sediment of many years' negligence." The stand, she writes, lacked visual impact, and was too cluttered, with no "filtering or focus," meaning that works that may have been relevant internationally were "lost in the melee of offerings." In her opinion, the promotional material was amateurish. The presentation of this, she writes, "requires the involvement of an expert in the field, if possible one who can create an advanced, high quality visual background for the presentation of Hungarian children's books" (Révész 2019).

Frequent restructuring of Hungarian state funding for the translation and promotion of Hungarian literature abroad may have contributed to this poor showing. There have been no fewer than four major changes to how state funding is managed since the independent Hungarian Book Foundation was founded in 1997. The latest of these took place in early 2019, when a new body, the Petőfi Literary Fund, was set up by the Hungarian state. Its website says that,

it is in charge of coordinating the Hungarian presence at international book fairs, it provides support for translators and publishing houses outside of Hungary, it helps people prominent on the Hungarian book market gain exposure outside the country, and it cultivates interest in Hungarian literature the world over with its own publications and media (Petőfi Literary Fund 2021).

Throughout the course of 2020, it awarded grants to early-career and established translators for the creation of sample translations. Similar grants were awarded to Hungarian and foreign publishers, and so-called 'micro-grants' were available to facilitate, for example, the travel of a Hungarian author to a book launch of a translated work abroad. The Petőfi Literary Fund also produced several English-language brochures in both paper and electronic format to publicize Hungarian literature at book fairs and other events. Two of these focused on children's literature: Children's Books: Publishers' Selection and New Hungarian Childlit 10.0 tales. As these publications have won a design award, perhaps, when it becomes possible to attend the Bologna Children's Book Fair once again - after the pandemic - they will make more of an impact than the promotional material Révész considered so "amateur."

Two grants were awarded in 2020 to the Hungarian publisher Csimóta for translation of a Hungarian children's book into English: an illustrated young adult novel by Ildikó Lipták: Csak neked akartunk jót ['We Only Wanted What was Best For You'] and a book of fiction for younger readers by Mari Takács: Bingaminga és a Babkák ['Bingaminga and the Beanlings']. While the grants for Hungarian publishers have a rolling deadline, the other grants have a limited timeframe. To date, however, no new calls for applications have been announced in 2021 for either early-career translators or established translators, and no new brochures have been produced. Whether this is an effect of the pandemic remains to be seen. 
Bentley, Anna. "The Fortunes of Hungarian Children's Literature at Home and in the English-Speaking World." Hungarian Cultural Studies. e-Journal of the American Hungarian Educators Association, Volume 14 (2021): http://ahea.pitt.edu DOI: 10.5195/ahea.2021.433

Another internationally visible forum is the IBBY Honor List, which is produced every two years by the International Board on Books for Young People, a "non-profit organization which represents an international network of people from all over the world who are committed to bringing books and children together" (IBBY 2021). The Hungarian Section, re-established as HUBBY in 2015, selects Hungarian works to be included in it, ensuring that a handful of Hungarian books will feature in the categories of writing, illustration and translation. The latest of these, listed in 2020, is Dóra Gimesi's A Macskaherceg kilencedik élete ['The Cat Prince's Ninth Life'] (Pagony 2017), a pair of modern fairy tales set firmly in present-day Hungary. This list is a resource for foreign publishers searching for a book to translate and publish. It is, however, very extensive, and the selections of current foreign children's literature and features done on a blog such as World Kid Lit are probably more useful.

Bringing Hungarian children's books to the English-speaking world is not an easy task, but an improved presence at the Bologna Book Fair and an increase in the number of personal connections between the Hungarian book world and UK and American publishers will hopefully make a difference.

\section{Hungarian Children's Literature Embroiled in Politics}

As we saw in the section on present-day Hungarian children's literature, Hungarian writers and publishers for children have in recent years been more willing to tackle areas of life previously considered taboo or off-limits to writing for children. As well as exploring periods of history that remain sensitive in Hungary, such as the Holocaust, Egy fiú a csapatból ['A Boy from the Team'] by Dóra Igaz) and the expulsion of ethnic Germans after World War Two (Szepi hazatérő lelke ['Szepi’s Spirit Returns Home'] József Békés, Littera Nova, 2002), writers have told stories about situations that often carry stigma or that present great difficulties for children, such as living with a disability (Szabadlábon ['Walking Free'] by Ágnes Mészöly, Tilos az Á 2016), having a parent who is an alcoholic (Children's Book of the Year award-winner A muter meg a dzsinnek ['Mom and the Jinns'] by Dóra Elekes, Csimóta 2017), and having serious illness in the family (Anyát megoperálták ['Mom's Had an Operation'] by Krisztina Tóth, Móra 2015). Racial prejudice is central to Dzsorden, Péter Horváth's young adult novel about a teenage Roma boy (Noran Libro, 2012), and xenophobia is touched on in Zsófia Bán's Rough 'n Tough Owl and Third Grade A. We have seen a feminist and multi-cultural re-evaluation of traditional cultural heritage such as folk tales and a focus on meeting and understanding marginalized groups in society, for example the homeless and the LGBTQ+ community (Eszter T. Molnár's $A$ kóbor szálló ['Hotel for Strays'] Pagony, 2018, and the book by Zsófia Bán mentioned above).

Most recently, and most controversially, we have seen a clash between those seeking to bring these kinds of topics to the attention of children and the "Christian conservative" values espoused and promoted by Viktor Orbán's ruling Fidesz party and other right-wing groups in the country. Under Fidesz, the Hungarian Parliament recently voted to insert a paragraph into the constitution defining the family on the traditional model and "defending" the institution of 
Bentley, Anna. "The Fortunes of Hungarian Children's Literature at Home and in the English-Speaking World." Hungarian Cultural Studies. e-Journal of the American Hungarian Educators Association, Volume 14 (2021): http://ahea.pitt.edu DOI: 10.5195/ahea.2021.433

marriage ${ }^{1}$. In December of the same year, it effectively banned LGBTQ+ people from adopting children by making marriage (an option not available to same-sex couples) a requirement for adoption.

In 2020, a row erupted about the publication of Meseország mindenkié ['Fairytales for Everyone'], a book of fairy tales featuring characters from various marginalized groups, including people of color, children living in non-traditional families (e.g. with a single parent), as an adopted child, and also LGBTQ+ people. The book was published by the Labrisz Lesbian Association. As the editor Boldizsár M. Nagy explained to Könyves Magazin ['Magazine of Books'], established authors were invited to contribute stories, but writing from younger, amateur writers was also welcomed. Contributors were expected to "work up classic stories in a new, creative way while maintaining a high literary standard" and also to "feature a marginalized group of some kind or a problem that was rarely dealt with" (Könyves Magazin 2020b). The classic literary tales reworked in the book include Bambi (Edit Szücs's Az özike agancsa ['Koni's Antlers']) and Thumbelina (Petra Finy's Panna élni megy ['Panna Goes Off to Live']) and The Snow Queen (Judit B. Tóth's A jégkirály ['The Snow King']), as well as traditional fairy tales such as Snow White and the Seven Dwarves (Eszter Gangl's Aranybarna ['Goldenbrown']), and even Ancient Greek myths (Krisztina Rita Molnár's Rubinpiros madár ['Ruby Red Bird']).

When Fairytales for Everyone came to the attention of the deputy leader of the far-right party Mi Hazánk Mozgalom ['Our Homeland Movement'] Dóra Dúró, she ripped pages out of it and shredded them publicly during an online press conference, then publicized this modern equivalent of book-burning on her Facebook page, declaring, "Our Homeland Movement does not tolerate children being exposed to homosexual propaganda in the form of abnormal lifestyles smuggled into story books and thereby lying to children, as homosexual princes are not part of Hungarian culture" (Quoted in Magyar Narancs Sept. 25, 2020).

\footnotetext{
${ }^{1}$ Hungarian Constitution L. Paragraph 1: "Hungary defends the institution of marriage as a union between a man and woman.... The basis of family relationships is marriage and the parent-child relationship. A mother is a woman, a father is a man.” Cited from Farkas, Ágnes Virág 2020.
} 
Bentley, Anna. "The Fortunes of Hungarian Children's Literature at Home and in the English-Speaking World." Hungarian Cultural Studies. e-Journal of the American Hungarian Educators Association, Volume 14 (2021): http://ahea.pitt.edu DOI: 10.5195/ahea.2021.433
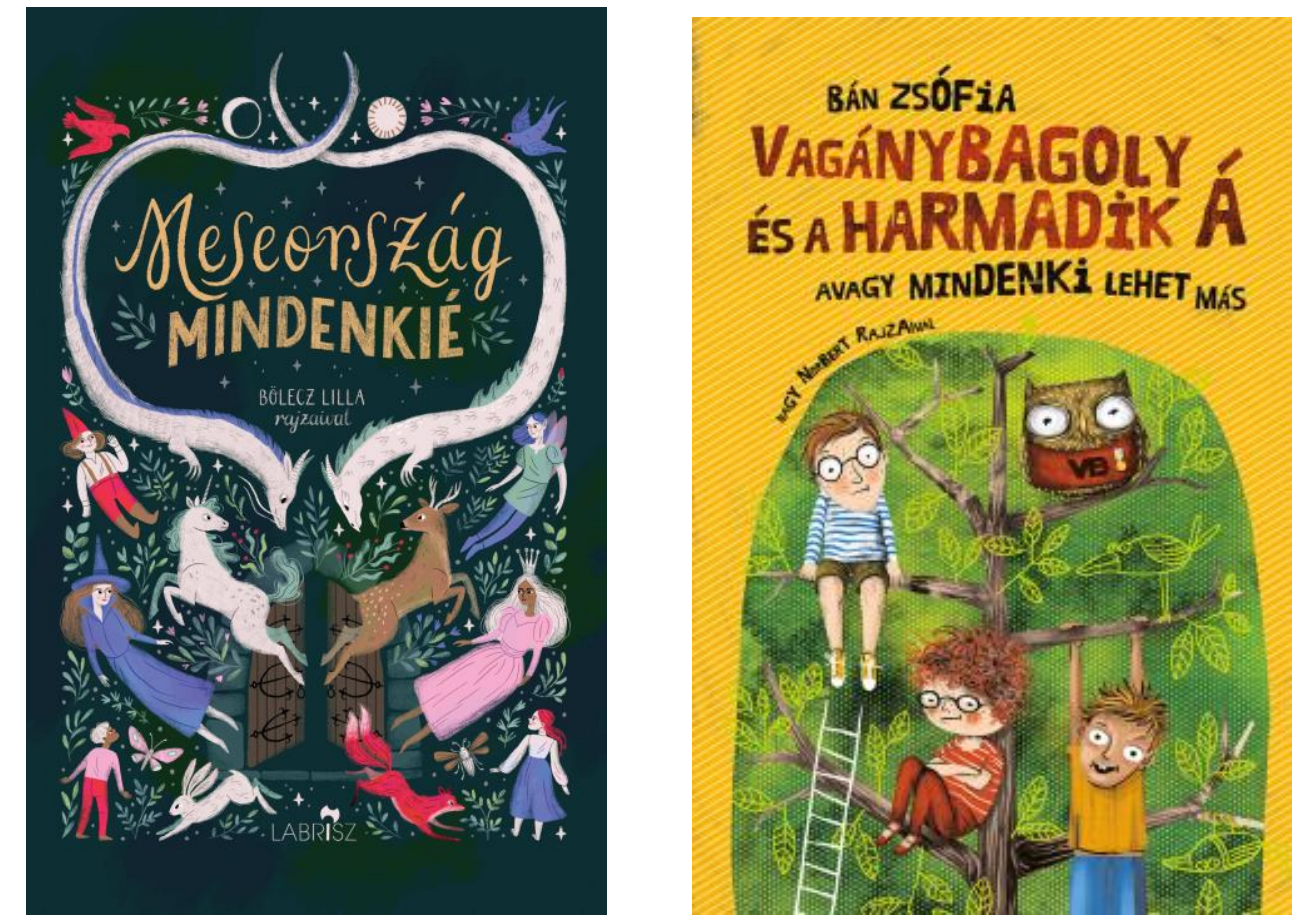

As Jozefina Komporaly reported in her article about the controversy for Asymptote, the online journal of translated literature, things did not stop there:

An unprecedented number of high-profile public figures took a stance against the book [including] numerous politicians, but also specialists in the humanities and the social sciences...this wave of rudimentary censorship continued with party activists boycotting public readings, displaying defamatory posters at bookshops selling the title, and with Dúró literally ripping apart another children's book. Vagánybagoly és a harmadik Á, avagy mindenki lehet más (Cool Owl and the Third A, or Everybody Is Entitled to be Different) was published in 2019, but it ended up on the receiving end of Dúró's rage simply because its author, Zsófia Bán, had previously delivered a speech at the opening of Budapest Pride (Komporaly 2020).

This attempt at censorship resulted in the book rapidly selling out. By the end of September 2020, those who wanted a copy had to place an order for the reprint. While this collection may not become a classic, it has opened up a debate about what the function of children's literature might be within society, and inside Hungary it has further pushed the boundaries of what children's literature can discuss.

Not long afterwards, a debate flared up about what children should or should not be reading at school, after the author Krisztina Tóth indicated, in response to a question put regularly to authors in a Q\&A column called "What Do Writers Read?" in Könyves Magazin that she believed $A z$ aranyember ['The Golden Man'], the nineteenth-century classic by Mór Jókai ought to be removed from the compulsory reading list. Not, she said primarily "on account of it being difficult for students to read and therefore off-putting to them, but because of the way the female characters are portrayed.... Our children construct their idea of what gender roles should 
Bentley, Anna. "The Fortunes of Hungarian Children's Literature at Home and in the English-Speaking World." Hungarian Cultural Studies. e-Journal of the American Hungarian Educators Association, Volume 14 (2021): http://ahea.pitt.edu DOI: 10.5195/ahea.2021.433

be from the books they read at school (Könyves Magazin, Feb 11, 2021). The female characters in Jókai's novel, she pointed out, are obedient to the men they love, and are undemanding, uncomplaining and unquestioning as they execute their domestic duties.

Her comments were picked up shortly afterwards in an article in Heti világgazdaság $(H V G)$ ['Weekly World Economy'], Hungary's economic and political weekly, after which, in the words of László Valuska, editor-in-chief of Könyves Magazin in his own article written two weeks later, "all hell broke loose" and "a bout of internet writer-lynching kicked off"(Valuska 2021). Tóth defended her position on her Facebook page and was bombarded with messages and letters from Jókai fans. Dog feces were even put in her letterbox. Valuska explains that "the reason we ask that question [Which book ought to be taken off the compulsory reading list?] is that the set books amount to a canon; they determine our lives and our reading habits. They even influence the picture we form of society" (Valuska 2021).

A lot is at stake, therefore, when decisions are made about what children must read at school. When the new Nemzeti Kerettanterv ['National Curriculum'] was published in 2020, some commentators were horrified to see that the Nobel Prize-winning author Imre Kertész, best known for his writings about the Holocaust, and the canonical author Géza Ottlik were missing from it, while authors better known for their right-wing views than their literary merit, such as Ferenc Herczeg and Albert Wass had been included. The Hungarian Teachers Association stated publicly that

[t]his curriculum once again makes literary education the handmaiden of ideology and politics and knocks the teaching of Hungarian back into a role from which it managed to free itself in 1978. The concept of literature it adopts, breaking as it does with, and opposing the linguistic realisation of, the works and their value to national cultural identity, is not conservative. It is outdated.... It highlights elements of the classroom material that present Hungarians as a persecuted people, emphasizes grief over Trianon and declares unity with Hungarians over the borders. While we do not dispute the legitimacy of that pain, nor the cross-border nature of Hungarian literature, we believe making that pain the guiding principle of literary history is an act profoundly hostile to literature itself (Magyartanárok Egyesülete 2020).

In this political environment it is, therefore, interesting to see Zsófia Bán's book Rough 'n Tough Owl and Third Grade A featured in the Petöfi Literary Fund brochure New Hungarian Childlit 10.0 and Krisztina Tóth's The Girl Who Didn't Speak featured in their Children's Books from Hungary: Publishers' Selection brochure.

It is to be hoped that more Hungarian children's books will come to the attention of American and British publishers through some or all of the channels I have discussed, whether those be online events such as the World Kid Lit panel discussion, a more effective presence at the Bologna Book Fair, a continuation (or resumption?) of grants for sample translations, travel expenses for authors and the publication of attractive brochures, or the efforts of Hungarian publishers and translators from Hungarian to select books that will appeal to such publishers and pitch them appropriately. There are bold publishers and many exciting new authors and illustrators to choose from in Hungary today, authors who, despite the current government's illiberal ideology and its efforts to skew the official canon towards the right, are acknowledging Hungary's diverse heritage and drawing on it for inspiration and subject matter. 
Bentley, Anna. "The Fortunes of Hungarian Children's Literature at Home and in the English-Speaking World." Hungarian Cultural Studies. e-Journal of the American Hungarian Educators Association, Volume 14 (2021): http://ahea.pitt.edu DOI: 10.5195/ahea.2021.433

(All translations are by the author)

\section{A List of Hungarian Children's Books Mentioned in the Article}

Bajzáth, Mária. 2018. A rabbi és az oroszlán ['The Rabbi and the Lion'] Kolibri.

Bán, Zsófia. 2019. Vagánybagoly és a Harmadik Á ['Rough 'n Tough Owl and Third Grade A'] Pozsonyi Pagony.

Bartos, Erika. 2004. Bogyó és Babóca ['Berry and Dolly'] Pozsonyi Pagony. (First in a series) Békés, József. 2002. Szepi hazatérö lelke ['Szepi’s Spirit Returns Home’] Littera Nova.

Békés, Pál. 1983. A kétbalkezes varázsló ['The Ham-Fisted Wizard'] Minerva.

Benedek, Elek. 1894 -1896. Magyar mese- és mondavilág ['The World of Hungarian Folktales and Proverbs'] Athenaeum Irodalmi és Nyomdai Rt.

Berg, Judit. 2006. Rumini Pozsonyi Pagony. (First in a series)

Dániel, András. 2013. Egy kupac kufli ['A Heap of Kuflis'] Pozsonyi Pagony. (First in a series)

Dániel, András. 2018. Tengerre kuflik! ['To Sea, Kuflis!'] Pozsonyi Pagony.

Dávid, Ádám and Gaborják, Ádám. (eds.) 2016. Jelen! - kortárs ifjúsági novellák ['Present! Contemporary Short Stories for Young Adults'] Móra Könyvkiadó.

Elekes, Dóra. 2017. A muter meg a dzsinnek ['Mom and the Jinns'] Csimóta.

Frankovics, György (ed.) 2015 A büvös puska ['The Magic Rifle’] Móra Könyvkiadó.

Gárdonyi, Géza. 1901. Egri csillagok ['The Eclipse of the Crescent Moon'] Légrády Brothers.

Gimesi, Dóra. 2017. A Macskaherceg kilencedik élete ['The Cat Prince's Ninth Life'] Pagony.

Horváth, Péter. 2012. Dzsorden Noran Libro.

Igaz, Dóra. 2018. Egy fiú a csapatból ['A Boy from the Team'] Pozsonyi Pagony.

Karinthy, Frigyes. 1916. Tanár úr kérem ['Please, Sir!'] Dick Manó.

Kertész, Erzsi. 2016. NEM mese ['The NO Story'] Pozsonyi Pagony.

Kertész, Erzsi. 2018. Labirintó ['Labyrinth Lake'] Cerkabella.

Kertész, Erzsi. 2020. Panthera 1. - A hógömb fogságában ['Panthera 1. - Trapped in the Snowglobe'] Pozsonyi Pagony. (First in a series)

Lázár, Ervin. 1981. Szegény Dzsoni és Árnika ['Arnica the Duck Princess'] Móra Könyvkiadó.

Lázár, Ervin. 1985. A négyszögletü kerek erdő ['The Four-Square Round Forest'] Móra Könyvkiadó.

Lipták, Ildikó. 2020. Csak neked akartunk jót ['We Only Wanted What Was Best For You'] Csimota.

Marék, Veronika. 1970. Annipanni és Boribon ['Annipanni and Boribon’] Móra Könyvkiadó. (First in a series)

Marék, Veronika. 1980. Kippkopp a füben ['Kippkopp in the Grass'] Móra Könyvkiadó. (First in a series)

Mészöly, Ágnes. 2016. Szabadlábon ['Walking Free'] Tilos az Á.

Mikszáth, Kálmán. 1895. Szent Péter esernyöje ['St. Peter’s Umbrella'] Légrády Brothers.

Molnár, Eszter T. 2016. Stand-Up! Egy majdnem normális család ['Stand-up! A Nearly Normal Family'] Tilos az Á.

Molnár, Eszter T. 2018. A kóbor szálló ['The Hotel for Strays'] Pagony. 
Bentley, Anna. "The Fortunes of Hungarian Children's Literature at Home and in the English-Speaking World." Hungarian Cultural Studies. e-Journal of the American Hungarian Educators Association, Volume 14 (2021): http://ahea.pitt.edu DOI: 10.5195/ahea.2021.433

Molnár, Ferenc. 1906. A Pál utcai fiúk ['The Paul Street Boys'] Franklin-Társulat. Móricz, Zsigmond. 1920. Légy jó mindhalálig ['Be Faithful Unto Death'] Athenaeum Kiadó.

Nagy, Boldizsár (ed.) 2020. Meseország mindenkié ['Fairytales for Everyone'] Labrisz Leszbikus Egyesület.

Takács, Mari. 2020. Bingaminga és a Babkák ['Bingaminga and the Beanlings'] Csimota. Tóth, Krisztina. 2015. A lány aki nem beszélt ['The Girl Who Didn’t Speak'] Móra Könyvkiadó. Tóth, Krisztina. 2015. Anyát megoperálták ['Mom’s Had an Operation'] Móra Könyvkiadó. Zágoni, Balázs. 2019. A gömb ['The Sphere’] Móra Könyvkiadó.

Zalkai, Csenge Virág. 2019. Ribizli a világ végén ['Redcurrant at the End of the World'] Móra Könyvkiadó.

\section{Hungarian Children's Books in English (and German) Translation}

Benedek, Elek. 2014. The Princess of the Wind, trans. Elizabeth Demeter, Corvina Gárdonyi, Géza. 1991. Eclipse of the Crescent Moon, trans. G. F. Cushing, Corvina Karinthy, Frigyes. 1968. Tanár úr kérem [Please Sir!] trans. István Farkas, Corvina Lázár, Ervin. 2019. Arnica the Duck Princess, trans. Anna Bentley, Pushkin Children's Press, London

Janikovszky, Éva. 1972. Große Dürfen Alles, Anrich, Mülheim-an-der-Ruhr.

Mikszáth, Kálmán. 1966. Szent Péter esernyöje [St Peter’s Umbrella] trans. B.W. Worswick, Folio Society.

Molnár, Ferenc. 1994. The Paul Street Boys, L. Rittenberg's 1927 translation revised by George Szirtes, Corvina.

Móricz, Zsigmond. 2015. Be Faithful Unto Death trans. Stephen Vizinczey, CEU Press.

\section{Works Cited}

Bird, Elizabeth. 2019. 'Guest Post - Beyond 3 Percent: Translated Children's Literature in the U.S.' School Library Journal blogs.slj.com/afuse8production/2019/11/12/guest-postbeyond-3-percent-translated-childrens-literature-in-the-u-s/ Accessed May 31, 2021

Donahaye, Jasmine. 2012. Three percent? Publishing data and statistics on translated literature in the United Kingdom and Ireland. Wales: Aberystwyth University.

Farkas, Ágnes Virág. 2020. “Az Orbán-kormány beleírja az Alaptörvénybe, hogy az anya nő, az apa férfi." ['The Orbán Government Writes into the Constitution that a Mother is a Woman, a Father a Man.'] Index. November 10 index.hu/belfold/2020/11/10/varga_judit_alaptorveny/ Accessed: May 31, 2021

Guardian 2020. 'Hungary's Parliament Blocks Domestic Violence Treaty' May 5 www.theguardian.com/world/2020/may/05/hungarys-parliament-blocks-domestic-violencetreaty Accessed: May 31, 2021

Hallford, Deborah and Zaghini, Edgardo (Eds.) 2005 Outside In: Children's Books in Translation. Milet Publishing. 
Bentley, Anna. "The Fortunes of Hungarian Children's Literature at Home and in the English-Speaking World." Hungarian Cultural Studies. e-Journal of the American Hungarian Educators Association, Volume 14 (2021): http://ahea.pitt.edu DOI: 10.5195/ahea.2021.433

2016. 'A Decade in Children's Literature in Translation (2005 - 2014)'

www.outsideinworld.org.uk/childrens-books.asp?page=ArticlesNewsandLinks Accessed:

May 31, 2021

IBBY (International Board on Books for Young People) 2021 'What is IBBY?' www.ibby.org/about/what-is-ibby Accessed: May 5, 2021

Komáromi, Gabriella. 1990. Elfelejtett irodalom ['Forgotten Literature'] Móra Könyvkiadó. p. 15 ------. 2014. Janikovszky Éva: Pályakép mozaikokban ['Éva Janikovsky: A Career Assembled from Fragments'] Móra Könyvkiadó. p. 250.

Komporaly, Jozefina. 2020. 'Silencing Tales for Tolerance in Hungary: Wonderland Belongs to Everyone', Asymptote Nov. 11 www.asymptotejournal.com/blog/by/jozefina-komporaly/ Accessed: May 31, 2021

Könyves Magazin ['Books Magazine’] 2020a “2020-ban ezek a könyvek esélyesek az Év Gyerekkönyve Díjára" ['2020 Children's Book of the Year Hopefuls'] March 23

konyvesmagazin.hu/gyerekirodalom/hubby_shortlist.html Accessed: May 31, 2021

Könyves Magazin. 2020b. "Meseország mindig is mindenkié volt, csak erről nem tudott mindenki" ['Fairyland Has Always Been for Everyone; It's Just That Not Everyone Knew About It.'] Oct 1

konyvesmagazin.hu/gyerekirodalom/nagy_boldizsar_duro_dora_meseorszag_mindenkie.ht ml Accessed: May 31, 2021

Könyves Magazin. 2021. “Tizenegyes - Mit olvas az író?” ['Eleven - What do Writers Read?:

Krisztina Tóth'] Interview by Anna Ott, Feb. 11

konyvesmagazin.hu/friss/tizenegyes_ott_anna_toth_krisztina_olvasas.html Accessed: May 31,2021

Lovász, Andrea. 2008. "Klasszicizálódó kortársak. Tendenciák a gyermek irodalomban" ['Contemporaries Becoming Classics: Trends in Children's Literature'] Könyv és Nevelés 4 folyoiratok.oh.gov.hu/konyv-es-neveles/klasszicizalodo-kortarsak-tendenciak-agyermekirodalomban Accessed: May 31, 2021

Magyar Narancs. 2020. "Dúró Dóra ledarált egy mesekönyvet, mert szerinte meseország nem az aberráltaké." ['Dóra Dúró Shredded a Storybook Because She Says Wonderland Does Not Belong to Deviants.'] Sept 25 magyarnarancs.hu/feketelyuk/duro-dora-ledaralt-egymesekonyvet-mert-szerinte-meseorszag-nem-az-aberraltake-133498 Accessed May 31 2021

Magyartanárok Egyesülete. 2020. "A magyartanárok egyesülete állásfoglalása a nemzeti alaptanterv 2020. január 31-én nyilvánosságra hozott szövegéröl” ['Resolution of the Hungarian Teachers' Association concerning the text of the National Curriculum published on January 31, 2020']

magyartanarok.wordpress.com/2020/02/01/a-magyartanarok-egyesulete-allasfoglalasa-anemzeti-alaptanterv-2020-januar-31-en-nyilvanossagra-hozott-szovegerol/ Accessed May 31,2021

Malmkjær, Kirsten. 2018. 'Children's Literature in/and Translation: The Oeuvre as Corpus' Ilha Desterro Vol.71 No.1 Florianópolis Jan./Apr. 
Bentley, Anna. "The Fortunes of Hungarian Children's Literature at Home and in the English-Speaking World." Hungarian Cultural Studies. e-Journal of the American Hungarian Educators Association, Volume 14 (2021): http://ahea.pitt.edu DOI: 10.5195/ahea.2021.433

www.scielo.br/scielo.php?script=sci_arttext\&pid=S2175-80262018000100135\#B8

Accessed: May 31, 2021

Móra Publishing House. 2020. Hungarian Literature in English for Children

https://mora.hu/content/2020/9/NewsItemFile/hungarian_literature_in_english_for_childre n_2020.pdf Accessed: May 31, 2021

Nagy, Boldizsár. 2019. “Felébresszük-e Csipkerózsikát?” ['Should We Awaken Sleeping Beauty?'] Magyar Narancs December 21. magyarnarancs.hu/konyv/felebresszuk-ecsipkerozsikat-124711 Accessed: May 31, 2021

Nagy Boldizsár. 2020. "A kuflik sokadjára is viccesek? (Spoiler: igen!)” [“Are the Kuflis Still Funny, So Many Books On? (Spoiler: Yes!)’] Magyar Narancs Sept 7 www.kritikusvagyok.hu/post/a-kuflik-sokadj\%C3\%A1ra-is-viccesek-spoiler-igen

Accessed: May 31, 2021

Nagy, Gabriella Ágnes. 2017. "Népmesei hagyomány a kortárs gyerekirodalomban. Tóth Krisztina: A lány aki nem beszélt" ['Folktale Tradition in Contemporary Children's Literature: Krisztina Tóth's The Girl who Didn't Speak.'] Tempevölgy 9/4. http://epa.oszk.hu/03000/03099/00036/pdf/EPA03099_tempevolgy_2017_4_055-072.pdf Accessed: May 31, 2021

Nemzeti Erőforrás Minisztérium. 2006. [Ministry of National Resources] "Magyarország a bolognai gyermekkönyvvásár díszvendég" ['Hungary is the Guest of Honor at the Bologna Children's Book Fair.'] www.nefmi.gov.hu/kultura/2006/magyarorszag-bolognai Accessed: May 31, 2021

Oktatási Hivatal. 2020a. Kerettanterv az általános iskola 1-4. évfolyama számára (Hungarian Education Authority Curriculum for Primary School Grades 1-4) www.oktatas.hu/kozneveles/kerettantervek/2020_nat/kerettanterv_alt_isk_1_4_evf Accessed: May 31, 2021

Oktatási Hivatal. 2020b. Kerettanterv az általános iskola 5-8. évfolyama számára (Hungarian Education Authority Curriculum for Primary School Grades 5-8) www.oktatas.hu/kozneveles/kerettantervek/2020_nat/kerettanterv_alt_isk_5_8/ Accessed: May 31, 2021

Petőfi Literary Fund. 2021 “About Us” https://plf.hu/about-us Accessed: May 5, 2021.

Pompor, Zoltán. 2010. “Egyesülésben az erő: Interjú Nánási Yvette-tel, a Magyar Gyermekkönyvkiadók Egyesülésének igazgatójával" ['Strength in Union: An Interview with Yvette Nánási, the Director of the Hungarian Children's Book Publishers' Union'] Prae April www.prae.hu/article/2648-egyesulesben-az-ero/Accessed: May 31, 2021

Révész, Emese. 2019. "Bologna-mérleg. Bolognai gyermekkönyv és illusztrációs vásár" ['Bologna Balance Sheet: The Bologna Children's Book and Illustration Fair']. Tiszatáj online. April 29. tiszatajonline.hu/?p=123383 Accessed: May 31, 2021

Valuska, László. 2021. "A Jókai-rajongók, a kutyaszar és az elnémítás kultúrája” ['Jókai Fans, Dog Shit and the No-platforming Culture.'] Könyves Magazin Feb 23. konyvesmagazin.hu/nagy/toth_krisztina_jokai_mor_kotelezo_olvasmany_tizenegyes_canc el_culture.html Accessed: May 31, 2021 